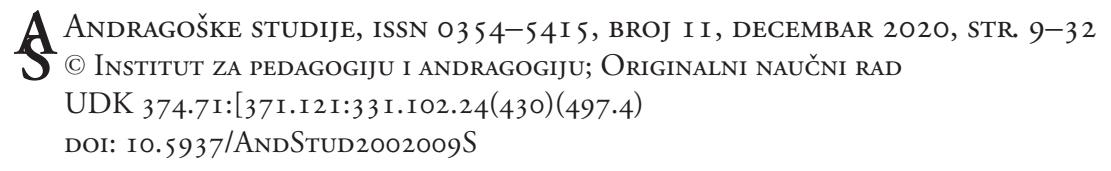

Jörg Schwarz ${ }^{1}$

Helmut Schmidt University, Germany

Borut Mikulec ${ }^{2}$

University of Ljubljana, Slovenia

\title{
The Role of Organisations in the Professionalisation of Adult Educators in Germany and Slovenia
}

\begin{abstract}
In this paper, we analyse the role that adult and continuing education (ACE) organisations play in the professionalisation of adult educators (AE) by providing and shaping opportunities for primary professional education and continuing professional development in two Central European countries: Germany and Slovenia. Theoretically, our discussion draws on classical profession theory, organisation theory, and the "new professionalism" discourse; empirically, we perform a comparative analysis between two countries and discuss similarities and differences in terms of state-society contexts, professional organisations, and professionalisation organisations. Our findings indicate that professional and professionalisation organisations represent main institutionalised contexts where the professionalisation of ACE is negotiated. In Slovenia, this is supported by strong state-society contexts, whereas in Germany, traditional regional and institutional diversity is achieved at the price of a unified AE occupational profile.
\end{abstract}

Key words: Germany, organisations, professionalisation of adult educators, Slovenia.

\section{Introduction}

The adult education research community (see, for example, Egetenmeyer, Breitschwerdt, \& Lechner, 2019; Jarvis \& Chadwick, 1991; Nuissl \& Lattke, 2008) and international organisations active in the field of adult and continuing education (ACE) (see, for example, Council of the European Union, 2011; DVV International, 2013) emphasise the importance of well-qualified personnel working in

\footnotetext{
${ }^{1}$ Jörg Schwarz, PhD is a Postdoctoral Researcher at the Helmut Schmidt University, Germany (joerg.schwarz@ hsu-hh.de).

${ }^{2}$ Borut Mikulec, PhD is Assistant Professor at the University of Ljubljana, Slovenia (borut.mikulec@ff.uni-lj.si).
} 
the field. However, the question of whether ACE should professionalise has been discussed since the 1920s. One camp is in favour of professionalisation, because it may help improve ACE's marginal status in society and quality; the other has been raising concerns that professionalisation may lead to the marginalisation or exclusion of different voices and approaches to adult education (cf. Merriam \& Brockett, 2007; Grotlüschen, Stammer, \& Sork, 2020). Furthermore, the range of professionals working in this field is wide and diverse, as ACE is linked to a country's social structure, its socio-economic, cultural, and political traditions and the low regulation of the ACE system (Jütte, Nicoll, \& Salling Olesen, 2011). Moreover, the field is characterised by fragmented training opportunities and precarious job status, with many adult educators (AE) working in the field lacking formal preparation for teaching, counselling, programme planning, and so on before entering the profession (Andersson, Köpsén, Larson, \& Milana, 2013).

In recent years, especially in the European educational space, studies of professionalisation focused mainly on competences that $\mathrm{AE}$ should have (see $\mathrm{Mi}$ kulec, 2019), but less attention has been given to the important role organisations play in the professionalisation of $\mathrm{AE}$. Organisations not only provide primary spaces for the (professional) development of $\mathrm{AE}$ (Breitschwerdt, Lechner, \& Egetenmeyer, 2019) but also emphasise, from a multi-level perspective on professionalisation, the general importance of interdependencies between the statesociety (macro), organisations (meso) and staff-personnel (micro) levels of professionalisation (Egetenmayer et al., 2019). Therefore, the aim of this paper is to fill this gap and to analyse the role ACE organisations play in the professionalisation of $\mathrm{AE}$ by providing opportunities for primary professional education and continuing professional development in two Central European countries, Germany and Slovenia, both of which have a long tradition in institutionalised forms of ACE. Furthermore, although the focus of the analysis is on organisations (meso level), these are reflected also through the state-society context (macro level). The paper explores the following research question: What kind of opportunities and programmes for the professionalisation of $\mathrm{AE}$ are offered by ACE organisations in Germany and Slovenia?

In the following, we first briefly introduce the theoretical framework. Next, we outline our methodological approach and provide an analysis of German and Slovene conceptualisations of the organisations' role in the professionalisation of AE. In the final section, we discuss the identified similarities and differences. We argue that professional and professionalisation organisations represent main institutionalised contexts in which the professionalisation of ACE is negotiated, whereas the state-society context plays a strong role in regulating this process, either by providing a binding common idea of $\mathrm{AE}$, as in Slovenia, or by holding 
back and leaving this to the competition of different ideas within a diverse field, as in Germany.

\section{Organisation and Professionalisation: A Complex Relationship}

Drawing on classical profession theory, organisation theory, and the discourse about a "new professionalism", we will first shed light on the complex relationship between organisations and professions before narrowing our examination to processes of professional education and development and the interplay between professions and organisations in these processes.

\section{"Organisation vs. Profession" and Organised Professionalism}

From the perspective of classical profession theory (Marshall, 1939), the relationship between professions and organisations can initially be characterised as tense, to say the least. Especially in the early sociology of professions in the 1930s, professions were described as antithetical to the modern economy and thus also to the societal organisation of work in the form of organisational hierarchies (e.g. large companies). In this context, professional autonomy is elevated to almost heroic status, which stands in the way of the integration of professional work into hierarchical organisational structures. At the same time, the development of new forms of professions is observed, which integrate their activities very well into the hierarchies of large organisations but are characterised as semi-professions and discredited as a result of a social advancement project of the middle class (see Marshall, 1939, p. 339).

In the influential structural-functionalist theory of professions (Parsons, 1939), the opposition of "professional man" and "business man" lives on but undergoes a more extensive theorisation, which, instead of assuming fundamentally different motivations for both (egoistic vs. altruistic), emphasises their commonalities (rationality and success orientation). As a result, the explanation of different forms of action is shifted to the level of "radically different" institutional patterns, which stem from their different social functions. Ultimately, for Parsons, it is the "professional complex" that during the $20^{\text {th }}$ century "has become the most important single component in the structure of modern societies" (Parsons, 1968, p. 545). Consequently, when Parsons finally states a closer interlocking with organisations in the further development of the professions, he sticks to the belief that a professional logic will play the dominant part in this relationship. 
But the increasing intertwining between professions and organisations that could be observed empirically over the course of the $20^{\text {th }}$ century can theoretically also be resolved in the opposite direction: In systems theory following Luhmann, Parson's idea of a professional complex as a social entity bridging different social systems is being questioned, because it contradicts the basic idea of functional differentiation - if such a bridging principle actually exists in modern societies, it is the organisation (Stichweh, 2006). In this point of view, the organisation in fact not only acts as a functional equivalent, it is also considered the more modern one, effectively acting as a successor of the professions once an advanced stage in functional differentiation is achieved (Kurtz, 2002).

The relationship between professions and organisations can also be viewed from a different angle if we focus not so much on the professions but on professionalism as a basic principle of social coordination. Thinking of professionalism as a "third logic" besides the market and bureaucracy (Freidson, 2001) opens up a connection to discourse in organisation theory. Not only markets and hierarchies (Williamson, 1973) and networks (Powell, 1990) but also professionalism may be analysed as a basic principle of social coordination that shapes the social relations both within organisations and between organisations. For example, Mintzberg's "professional bureaucracy" (Mintzberg, 1989) is an ideal-typical connection of professional and bureaucratic/hierarchical governance mechanisms. For organisational fields, the sociological neo-institutionalist perspective assigns an important role to professionalism, particularly in relation to the concept of normative isomorphism, and thus for both social reproduction and social change (Greenwood, Suddaby, \& Hinings, 2002; DiMaggio \& Powell, 1983, p. 152).

Thinking of organisations and profession(alism) as two distinct forms of social coordination in general and of the societal coordination of work and knowledge in particular opens up the possibility to analyse their hybridisation as an absolutely typical phenomenon in late modernity: The theoretical approach of a "new professionalism" hence not only highlights the general significance of "organisational professionalism" but also emphasises the opportunities connected with it, leading to new empirical approaches (see Egetenmeyer et al., 2019; Schwarz, 2016).

\section{Organisations' Role in the Professionalisation of ACE}

In classical profession theory, organisation (in the broader sense) plays an important role for the professions, mainly with respect to the self-organisation of a professional community, such as a professional association (with organs, codified rules, defined membership, and so on). These professional associations act as (political) representatives of professional interests, not least with regard to the 
education and training of novices (see Goode, 1957, p. 195). However, the idea that the professional community (association) controls admission to and contents of training on the level of both primary and further professional education and training is being thwarted by the changing relationship between organisations and professions, as well as by different socio-cultural contexts, national, and (partly) supra-national regulations. Vast differences emerge, for example, between the Anglo-American and the continental European institutionalization process, with the state serving as the central regulatory instance, especially with regard to formal education, in the latter case (Mieg, 2016).

Therefore, to examine the role organisations play in the professionalisation of AE, we must adopt a research perspective that allows us to focus on the complex relations between different professional and professionalisation organisations:

(1) Professional organisations: First, we can examine professional associations in the narrow sense, that is, associations self-organised by professionals from the field of ACE. We can expect to find such associations on different levels, ranging from associations of educators in general to much smaller, field-specific associations (e.g. for freelance trainers in VET), and they may or may not be hierarchically linked (e.g. by an umbrella organisation). Second, we can examine academic associations, given that the relationship between the academic discipline and the profession of ACE cannot be safely assumed to be a very close one. However, although academic associations have an important influence on primary professional education in universities, they may act according to a logic fundamentally different from that of the field of professional practice. Third, we can also examine the interrelation of ACE organisations and their associational structures, which may influence both primary professional education and further professional development.

(2) Professionalisation organisations: Professional education is carried out predominantly in organised contexts. Theoretically, we could also examine informal learning and socialisation in the everyday practice in ACE organisations, but in our empirical investigation, we will deliberately exclude this case and focus on the formal and non-formal education of (future) professionals. Here, we can distinguish between (a) primary professional education and (b) continuing professional development. We assume formal study programmes at the university level to play a major role for the first category, whereas primary professional education may also occur in non-formal education programmes. Moreover, as a result of general processes of privatisation in academia and ongoing academisation, hybrid forms can also be 
expected here. For the second one, we expect ACE providers to play a major role. Moreover, providers may play a dual role: As members of provider associations, they negotiate the professionalisation of AE; as individual organisations, they provide further education for $\mathrm{AE}$ and thus simultaneously act as professionalisation organisations.

\section{Methodology}

For the comparative empirical analysis, we selected Germany and Slovenia, both of which are Central European countries and European Union (EU) member states, but with different histories, governance structures, welfare regimes, and ACE systems (Desjardins, 2017). Historically speaking, both countries have a long tradition in institutionalised forms of ACE; in 2019, for example, many adult education centres in Germany (Volkshochschulen) celebrated their $100^{\text {th }}$ birthday (Field, 2019), while in Slovenia, the Association of Folk Universities of Slovenia celebrated its $60^{\text {th }}$ birthday; the first folk school started to operate in 1921 (Mermolja, Benko, Grželj, \& Ličen, 2019). Today, the main focus of the ACE system in both countries is on vocational education and training (VET). In both countries, ACE is provided by a diverse range of organisations, including adult education centres/ folk schools, third age universities, schools, private institutions, companies, chambers of industry and commerce, institutions of higher education, and associations (in Germany also trade unions, political parties, church institutions, family education centres, and distance learning institutions; in Slovenia also libraries, museums, and galleries). However, the two countries differ in their governance of ACE systems: In Germany, ACE is overall less regulated than other parts of the education system, and the responsibilities for its legal regulation, the public recognition of providers, and their basic funding rest mainly with the sixteen states (Länder), whereas in Slovenia, the governance of ACE is mainly state based, with the ministry responsible for education and the ministry responsible for labour having the main responsibilities, but they are also supported by other ministries and relevant national bodies (Desjardins, 2017; Eurydice, 2020; Grotlüschen \& Haberzeth, 2018; Mikulec \& Jelenc Krašovec, 2016).

Three different comparative categories were developed to guide our comparison: (a) state-society context, (b) professional organisations, and (c) professionalisation organisations. Professional and professionalisation organisations are described in terms of the opportunities and programmes they offer - focusing on aims, target groups, and core contents - for the professionalisation of AE.

As regards the selection of sources, we analysed policies and regulations, organisations' webpages and their publicly available documents (e.g. statutes, 
reports, etc.), as well as articles, chapters, and books on professionalisation in Germany and Slovenia. Moreover, as natives of Germany and Slovenia, we could interpret the sources available in the national languages, and we are knowledgeable about the political context and ACE in the two countries.

\section{Germany}

At the turn of the $18^{\text {th }}$ and $19^{\text {th }}$ centuries, ACE in Germany emerged as a modern mass phenomenon under the term "Volksbildung" (popular education). Institutionally, it took the form of bourgeois self-education in clubs and salons, urban education for craftsmen and workers, and rural popular education. Working as a popular educator was a voluntary and usually part-time activity carried out by (academically) educated citizens (doctors, lawyers, teachers) or local priests (Seitter, 2007). After steady expansion over the course of the $19^{\text {th }}$ century and with a new surge in institutionalisation at the beginning of the $20^{\text {th }}$ century, AE not only saw a new level of nationwide organisation but also the emergence of new professional tasks in the area of organisation, planning, and management. In post-war Western Germany, the comprehensive educational reforms of the $1960 \mathrm{~s}$ and 1970s established ACE as the fourth pillar of the education system with broadly accessible, publicly funded offerings in pluralistic institutional contexts, but also with commercial programmes by private ACE providers and VET within enterprises gaining importance. In the wake of this reform, professionalisation saw a new surge, linked to the establishment of a degree course in education ("Diplom-Pädagogik") introduced in 1969: With ACE offered as one of the major concentrations, academically trained AE entered the field for the first time. Although this degree programme was not created at the request of ACE providers or practitioners, the underlying concept of the ACE professional as a full-time occupation with an emphasis on management tasks eventually became a successful project, which is also mirrored in the massive increase in full-time professional activity during subsequent decades (Seitter, 2007).

\section{State-society context}

In Germany ACE is not uniformly or strictly regulated. This also applies to concepts of ACE professionals and their qualification: In the context of state recognition and basic funding of providers regulated by the continuing education laws of Germany's 16 states, the requirements concerning the qualification of the AE are either limited to formal aspects (e.g. a full-time head of the provider organisation) 
or remain rather vague (e.g. by referring to "professional aptitude"). At the same time, the last decades have seen an overall trend towards an ongoing decrease in basic funding for providers by the state governments, while funding earmarked for specific projects and programmes is becoming increasingly important. Federal policies, especially social, labour, and economic policies, thus play an important role for the developments in $\mathrm{ACE}$ and may influence the professionalisation of AE. But whereas ACE obviously plays an important role in addressing social challenges (BAMF, 2019, p. 130), general adult education is rather neglected, with policies focusing more on continuing VET, which is clearly evident in the (first!) national continuing education strategy, for example (BMAS \& BMBF, 2019).

\section{Professional Organisations}

In this section, we examine $\mathrm{AE}$ professional associations, providers' associations, and academic associations in Germany. Overall, we must assume an extremely low rate of self-organisation among adult educators, especially if compared to "classical professions" in Germany, where more than half (law, 53\%) or almost all professionals (medicine, 94\%) are members of a professional association (Martin \& Langemeyer, 2013, p. 56). Moreover, instead of a single professional association for AE, a variety of associations with different members and objectives have developed (so far).

\section{(1) Professional Association of Educational Scientists (BVPäd)}

BVPäd is the association whose characteristics most closely reflect the idea of professional self-organisation: Tightly connected to the professionalisation of (adult) educators, it was established in the 1970s, in the wake of the new degree programme in "Diplom-Pädagogik". This means that this association was never specific to $\mathrm{AE}$ but more to the graduates of this degree programme, who entered various areas of education under the professional title of "Diplom-Pädagoge". Its close historical relation to the abovementioned study programme posed challenges to the association during the Bologna process, because it had to redefine membership policies. Today, members must have completed a programme with a major in education, and the association is still clearly promoting the idea of the well-rounded, academically educated professional. Accordingly, academics are often active in the association, and it publishes an academically recognised journal. But with an estimated number of 500 members, the association only covers a fraction of the academically educated (adult) educators in Germany (Martin \& Langemeyer, 2013, p. 56). 
(2) Trainers' associations (dcvt, BDVT)

Other associations are not so much defined by the classical idea of a profession but organised around certain professional activities. Although there is no association explicitly for people doing ACE, there are several associations focussing on marketable professional services like "training", "counselling", and "coaching". The "German Association for Coaching and Training" (dvct, 1,600 members) or the "Professional Association for Training, Counselling and Coaching" (BDVT, 650 members) are two of the largest and best-known associations. They are also explicitly committed to professionalisation, both at the level of VET policy and through qualification and certification programmes for their members, but they do not aim for disciplinary closure. At the same time, its most important member group are self-employed individuals or freelancers in the respective fields of action.

\section{(3) The German Adult Education Association (DVV)}

The DVV ("Deutscher Volkshochschulverband") represents the ACE centres and their state-specific associations at the federal level. It not only promotes the exchange of experience and cooperation among its members but is also a political advocate of ACE in general. In this context, the quality of ACE plays an important role; therefore, the professionalisation of $\mathrm{AE}$ is also a relevant topic.

\section{(4) Catholic/Protestant Providers Associations (DEAE and KEB)}

According to the institutionalisation of ACE in Germany, confessional ACE providers play an important role: The "German Protestant Working Group on Adult Education" (DEAE) acts as an umbrella organisation for all providers of Protestant ACE, while the "Catholic Federal Working Group for Adult Education" (KEB) is the Catholic counterpart. Both associations aim at fostering cooperation between all Protestant resp. Catholic ACE providers and act as political lobbyists for them; at the same time, they are more generally committed to the further development of ACE in general, for example by running development projects on today's key issues.

\section{(5) The Wuppertal Circle}

The Wuppertal Circle represents the continuing education that takes place within companies and is the result of a cooperation of various trade associations like the "Federal Association of German Industry" (BDI), the "Association of German 
Chambers of Industry and Commerce" (DIHK), and others. The Wuppertal Circle also has a potential impact on professionalisation in ACE, given its concern with quality assurance in continuing education and its role as a representative of business interests in education policy issues.

(6) German Educational Research Association (GERA)

GERA is the association of educational researchers working in research and teaching at universities. Founded in 1964, the purpose of the GERA is to promote research, education, and training in the field of scientific pedagogy. Since ACE is considered a subdiscipline of education, it is represented by one of GERA's 14 divisions. In addition to its primary function as an academic association, it also has an important role to play in professionalisation: The association influences the education of $\mathrm{AE}$ at universities, for instance by defining a "core curriculum" (DGfE, 2006), and it represents scientific interests vis-à-vis educational policy and ACE practice.

(7) German Association for University Continuing and Distance Education (DGWF)

The DGWF is a hybrid organisation, because it is not only an academic association but could also be classified as a professional or even a providers' association: Its members are institutions and individuals from the higher education and continuing education sector, and its aim is to promote, coordinate, and represent continuing education provided by the universities. At the same time, it also promotes research and teaching in the field of ACE.

(8) German Institute for Adult Education (DIE)

The DIE is a non-university research institute committed to mediating between ACE research, practice, and politics. Its activities focus on: (a) supporting ACE research and other disciplines producing findings on lifelong learning (LLL) with publications and research data, (b) knowledge that contributes to the "development and sustainable professionalisation of practice" (DIE, 2017). DIE is classified as a scientific organisation here because it was founded as a pedagogical working group ("PAS") of the DVV and because its direct engagement in the training of $\mathrm{AE}$ (developed courses and self-study material) played a vital role especially during the 1970s (Gieseke, 2008). 


\section{Professionalisation Organisations}

More than 60 German universities offer degree courses in education, including more than 80 bachelor's degree courses and over 100 master's degree programmes (Grunert et al., 2016, p. 20ff). Usually, the bachelor's degrees are more general, whereas the master's programmes are often more specialised: ACE may be found explicitly in the title of the degree programme or as a specialisation in a general master's programme (in the tradition of "Diplom-Pädagogik"). In bachelor's programmes, students will learn the basics of education, social science research methodologies, and the historical, political, and social contexts of education. They will also have an introduction to the different specialisation options provided at the specific university (such as social pedagogy, rehabilitation pedagogy, ACE, etc.). Based on this introduction, they choose their specialisation and then learn about the history of ACE, relevant theoretical basics on ACE, and professional competences and careers in ACE. Master's programmes are usually more specialised from the beginning, leading to a master's thesis, which should also be anchored within the chosen specialisation in ACE (DGfE, 2006).

Professionalisation through continuing education is provided by many different organisations. Just as any other courses, trainings for AE may be offered by public, private, or third sector providers. The "basic qualification adult education" courses provided by many adult education centres (VHS) are one example: They aim at teachers and prospective teachers in ACE. The structure and contents of these courses may vary between the different VHS and especially between their 16 state-based associations, but they are mutually recognized nationwide. Similar courses are provided by the chambers of industry and commerce, the churches, or commercial providers. Now that the universities have established themselves as providers on the further education market in recent years, they also offer courses that provide graduates of various (non-pedagogical) subjects with basic qualifications in ACE, preparing them to work as teachers in ACE.

\section{Slovenia}

Historically, the professional development of AE in Slovenia can be traced back to the late 1950s, when Slovenia was part of Yugoslavia ${ }^{3}$. The training of the non-qualified adult population and the growth of institutional structures of ACE created a need for trained AE. Consequently, the systematic training of AE was first established at the People's and Worker's Universities (1957-1959).

\footnotetext{
${ }^{3}$ Slovenia was part of Yugoslavia until 25 June 1991 when it declared its independence.
} 
In the 1960s and 1970s, Yugoslavian universities opened the door to systematic theoretical and empirical research in the field of ACE and introduced study programmes on "andragogy" at the Faculties of Arts. Because of the helpful social climate, a new profession called "andragogue" emerged. In Slovenia, andragogy was introduced as a subject in higher education in 1972. From 1976 on, andragogy was one of the three possible fields of study in the study programme "Pedagogy"; in 1993, an independent study university programme "Andragogy" was established. Yugoslav (and thus Slovene) experience therefore pointed out the interdependence between andragogy as a science and the andragogue as a professional, the main outcome of this process being the awareness that people working in ACE needed to acquire a certain amount of andragogical knowledge (see Mikulec, 2019, pp. 33-34).

\section{State-society context}

ACE in Slovenia is one of the areas where the educational requirements for professionals - these being defined as teachers, organisers of ACE, counsellors in ACE, and "other professionals" - working in formal and non-formal educational programmes for adults, financed by public funds, are regulated by the law (Zakon o izobraževanju odraslih [ZIO], 2018). The obligatory conditions that AE working in formal and non-formal ACE programmes must fulfil are as follows: (a) mastery of the Slovene language; (b) education acquired through master's study programmes; (c) pedagogical-andragogical education; (d) successful completion of a professional examination in the field of education; that is, graduates who finish higher education studies are obliged to complete a traineeship lasting from 8 to 10 months before employment (Ministrstvo za šolstvo in šport, 2011; ZIO, 2018). However, these rules do not apply to all of those AE who work in ACE provisions that are not publicly funded, for example in enterprises that provide a high and growing share of continuous VET to employees.

Furthermore, the Resolution on the Master Plan for Adult Education in the Republic of Slovenia for the period 2013-2020 (National Assembly, 2013), which complements ACE law (ZIO, 2018; cf. Mikulec \& Jelenc Krašovec, 2016, pp. 155-156), sets more concrete goals for the development of ACE professionals: (a) a sufficient number of professionals should be trained for different target groups and needs; (b) a database of AE should be maintained for public service in ACE; (c) pedagogical-andragogical education should be adapted to different target groups; (d) quality teaching materials, learning resources and ICT-support should also be provided (National Assembly, 2013, p. 18). 


\section{Professional Organisations}

Professional organisations active in ACE are: (1) Andragogical Society of Slovenia, (2) Association of Folk Universities of Slovenia, (3) Slovenian Third Age University, National Association for Education and Social Inclusion, (4) Association of Adult Education Organizations in Upper-Secondary Schools, and (5) Association of Educational and Counselling Centres of Slovenia. Therefore, no single professional association exists in Slovenia, but a variety of associations can be found, serving different objectives and needs of its members. However, the existing studies show that the majority (almost 70\%) of AE continuing professional development takes place inside the organisation they work for or the association they are part of (Ministrstvo za šolstvo in šport, 2011).

\section{(1) Andragogical Society of Slovenia (ADS)}

ADS, established in 1968, is a non-profit professional association of AE employed in organisations that provide ACE, such as Folk Universities, private ACE companies, ACE organisations in upper-secondary schools, special education centres, and other services that provide ACE in voluntary, non-governmental and/or local organisations. The main aim of the association is to provide general public information about educational opportunities, to raise the quality of education, and to inform employees about innovations in ACE (ADS, 2020). Among others, one of the activities of the ADS, dating back to the 1980s, is professional training of AE. In recent years, the association focused on (a) ACE in communities, training municipal administration staff for the preparation of annual ACE plans on the municipal level, and (b) training of AE working with adults with special needs (association prepared special training programme). Furthermore, each year the association prepares an annual conference at the national level and is involved in the professional development of $\mathrm{AE}$ coming from the territory of former Yugoslavia in the network "Building Bridges in Adult Education" (ADS, 2020; personal communication with Ida Srebotnik, ADS, 14 June 2020).

(2) Association of Folk Universities of Slovenia (ZLUS)

ZLUS, established in 1959, is a non-governmental and non-profit professional association of 22 (out of 33) Folk Universities currently active in Slovenia. Folk Universities are one of the most important public organisations for ACE, serv- 
ing the needs and interests of adult learners (e.g. unemployed persons, migrants, older adults) and social partners (e.g. employers) in the local environment. The main mission of ZLUS is to represent the interests of its members and to promote LLL through the emphasis on ACE (Mermolja et al., 2019). Among other activities, ZLUS has provided training programmes for AE since the 1960s. Four such programmes are currently available: training of $\mathrm{AE}$ for the career guidance process; legality and quality assurance; working with prisoners; and mentoring in companies (ZLUS, 2020).

(3) Slovenian Third Age University, National Association for Education and Social Inclusion (U3A)

U3A, established in 1984, is a professional association that aims at improving the lives of older people and communities through education and culture, especially by giving older people access to culture and education for personal growth, better employability, active citizenship, active ageing, and the like. U3A is the largest Slovenian older ACE network, combining 53 third age universities in 51 localities. One of the basic roles and tasks of the association, since 1985, when the first trainings of leaders and mentors in the education of the elderly started, has been to take care of the professionalisation of the network's members. The network performs this task systematically by training leaders, mentors, animators, and other associates. Moreover, the training programme for mentors became mandatory for all mentors working in U3A organisations from 2010 on (U3A, 2020).

(4) Association of Adult Education Organisations in Upper-Secondary Schools (DOIO)

DOIO, established in 1997, is a voluntary, non-profit and professional association that connects $\mathrm{AE}$ who are employed in units of ACE at upper-secondary schools or school centres. The association was established to implement common tasks in the development of ACE in upper-secondary schools, for mutual cooperation and coordination of the role of ACE in Slovenia. The association monitors ACE in upper-secondary schools and takes care of its professionalisation by organising professional meetings and lectures on current issues and by representing common opinions on the issue of ACE in formal education at the national level (DOIO, 2020). 
(5) Association of Educational and Counselling Centres of Slovenia (ZiSS)

ZiSS is a newly formed association of centres for LLL for adults, which currently consists of 8 members, so called "Adult Education Guidance Centres" (ISIO) based at public Folk Universities. The association aims to develop and promote counselling activities in ACE and to actively support the development of ACE in Slovenia. The association also provides its members with training programmes (e.g. on issues related to occupational health and safety) and professional development opportunities (e.g. study visit programmes with different ACE organisations in Europe) (ZiSS, 2019; personal communication with Maja Radinovič Hajdič, ZiSS, 10 June 2020).

\section{Professionalisation Organisations}

Two main professionalisation organisations responsible for primary education and continuing professional development of AE discussed below are: (1) universities, responsible for primary professional education, and (2) the Slovenian Institute for Adult Education, responsible for continuing professional development. However, different public, private, and third sector ACE providers also provide different training courses for the professional development of AE.

\section{(1) Universities}

The University of Ljubljana, Faculty of Arts, offers doctoral and master's programmes in "Andragogy"; subjects covering ACE can be studied at the undergraduate level in the bachelor's programme "Pedagogy and Andragogy" (Filozofska fakulteta, 2021a). The University of Primorska, Faculty of Education, offers a master's programme in "Adult Education and Career Development"; subjects covering ACE can be studied at the undergraduate level in the bachelor's programme "Education/Pedagogy" (Pedagoška fakulteta, 2021). ACE as a subject can also be studied through the first- and second-cycle study programme of "Pedagogy" at the University of Maribor, Faculty of Arts (Filozofska fakulteta, 2021b) and through some other study programmes as well (e.g. Organisation and Management, Human Resources). Therefore, all three of Slovenia's public universities offer study programmes at the master's level or ACE subjects at the bachelor's level. Study programmes are aimed at full-time students and prepared in line with the Bologna requirements that took force in 2009. Broadly speaking, master's programmes in 
andragogy or ACE equip students with generic competencies in the humanities and social sciences, as well as with professional competencies that enable them to comprehend the relations between various ACE phenomena and processes, social and cultural environments, and the characteristics and expectations of individual adults.

Professional training for education professionals called "pedagogical-andragogical education" is also organised at the university level. These education programmes (for professionals working in primary and secondary schools and vocational colleges) aim at expanding the knowledge acquired in the academic education programmes and include pedagogical, psychological, andragogical, general, and specialised didactic knowledge, as well as pedagogical or andragogical practice. They are defined by laws and regulations and are mandatory prior to engaging in other professional or management work in the field of education (Filozofska fakulteta, 2021c).

\section{(2) Slovenian Institute for Adult Education (ACS)}

ACS, established in 1991, is an umbrella institution for ACE in Slovenia, and among others, the main institution responsible for the system of further education and training of AE. ACS developed competence-based professional training programmes for $\mathrm{AE}$, which aim to develop new knowledge and skills and help them to develop their own and the common professional identity of an AE. Three main types of professional training were developed: (a) general basic and continuing training of $\mathrm{AE}$ (knowledge of the discipline, andragogical cycle), (b) basic training on the special roles of $\mathrm{AE}$ (e.g. head and mentor in study circles, teacher in literacy programmes, counsellor in adult education guidance centres), and (c) further training of AE (ACS, 2015). These programmes are divided in two groups: (a) general and further non-formal training of $\mathrm{AE}$ ( 42 programmes), associated with identifying educational needs, planning of education, implementation of education, evaluation of education, management and administration and general ACE; and (b) basic non-formal training for special roles of AE (9 programmes), associated with basic non-formal education, quality in adult education, literacy in adult education, and guidance and counselling in ACE (see ACS, 2020).

\section{Comparison and Interpretation}

Historically, both Germany and Slovenia (as part of Yugoslavia before independence) have long traditions in institutionalised forms of ACE dating back to the first half of $20^{\text {th }}$ century, with organisations and their associations in ACE playing 
a crucial role in the primary and continuing professional development of AE. In the late 1960s (in Germany) and mid-1970s (in Slovenia), both countries saw a new surge of professionalisation through higher education degree programmes called "Diplom-Pädagogik" or "Pedagogy", where ACE/andragogy was one of the main branches of study, and academically trained AE entered practice. However, although academic opportunities for professionalisation of AE existed in both countries- and still exist today - the majority of $\mathrm{AE}$ working in practice did not study ACE but come from diverse disciplines. Furthermore, AE working in the public sector face precarious job situations and work mostly part time (Ministrstvo za šolstvo in šport, 2011; Martin et al., 2016; Mohorčič Špolar, 2011), whereas those working in the commercial or industrial sector may experience more prestigious jobs and seniority (Grotlüschen et al., 2020, p. 128). This pattern is not unique to Germany and Slovenia but can be recognised internationally, mostly caused by the heterogeneity of the field (Andersson et al., 2013; Grotlüschen et al., 2020).

The two countries differ from a macro perspective as well. In Slovenia, the educational requirements for $\mathrm{AE}$ working in publicly funded formal and nonformal educational programmes (Slovene language, master's degree, pedagogicalandragogical education, and internship) are regulated by the ACE law; the field of ACE is also regulated by other school and employment acts (see Mikulec \& Jelenc Krašovec, 2016, p. 156). On the policy level, clear support for the professional development of AE is set as well. However, although we could argue that policymakers and legislators do take care of the professional development of $\mathrm{AE}$, some recent studies show that teachers working with adults are often unwilling to learn about the specifics of adults and their learning needs (cf. Mohorčič Špolar, 2011). In Germany, on the contrary, no special law regulating educational requirements for $\mathrm{AE}$ is in place, but different laws on continuing education regulate the field. However, these laws can address the conditions of AE qualifications through the quality assurance mechanisms required for ACE providers to receive public funding. Some specific laws, such as the Immigration Act, also regulate the required qualifications of teachers working with adult migrants. However, this contributes more to a further specialisation and differentiation of occupational roles than to a shared concept of AE.

From a meso perspective, both countries share important similarities as they provide different opportunities for the (primary and continuing) professional development of AE. Existing studies for both countries show that organisations, supported by their associations or umbrella organisations, play a crucial role in the professionalisation of $\mathrm{AE}$, providing the primary space for the professional development of a great majority of AE working in practice (cf. Min- 
istrstvo za šolstvo in šport, 2011; Breitschwerdt et al., 2019). In our analysis, we identified different (1) professional organisations and (2) professionalisation organisations that exist in both countries and strive, among other goals, for the professionalisation of AE:

(1) Professional organisations: Neither country has a single professional association for $\mathrm{AE}$. Rather, a variety of associations with different objectives can be found, which makes it more unlikely that novices in the field will become members of an association just as a matter of course. In both Germany and Slovenia, professional associations and providers' associations can be found, but academic associations are only found in Germany (see Table 1). Professional associations in Germany strive for academically educated educators (BVPäd) or promote marketable professional services, such as counselling and coaching (BDVT, dvct). In Slovenia, only one such association exists (ADS), which in recent years has focussed on the continuing professional development of $\mathrm{AE}$ working with adults with special needs and on the training of municipal staff. Furthermore, the most common types of association in both countries are providers' associations (see Table 1), which promote cooperation among their members, serve their interests, are concerned with quality assurance in continuing education, and provide different professional training programmes for AE. Whereas providers' associations in Germany also act as umbrella associations (in case of DEAE, KEB and Wupertal Circle), no such umbrella organisation exists in Slovenia. Finally, Germany also has academic associations that promote professionalisation through the core curriculum or research and teaching, no such academic association was identified in Slovenia (see Table 1).

(2) Professionalisation organisations: In both countries, universities are the main organisations that provide primary ACE through relevant study programmes. At the bachelor's level, subjects covering ACE are available mainly through study programmes in Education/Pedagogy, whereas a specialisation in ACE is offered at the master's level. This trend is not specific to the countries analysed here, as the majority of European university study programmes offer a specialisation in ACE at the master's level as well (cf. Research voor Beleid, 2010, pp. 105106). However, unlike German universities, Slovenian universities also provide "pedagogical-andragogical education", which, according to the regulations, all candidates must complete before engaging 
in professional work in the field of education. Furthermore, whereas continuing education programmes aiming at the professionalisation of $\mathrm{AE}$ are provided by different (public, private, third sector) ACE providers in both countries, the Slovenian ACS, as an umbrella organisation, is also responsible for the development and maintenance of the system for the continuing education of AE (see Table 1). For this purpose, ACS developed and offers more than 50 different programmes to $\mathrm{AE}$, and it annually evaluates participants' satisfaction with the programmes offered.

Table 1. Professional and professionalisation organisations in Germany and Slovenia

Germany Slovenia

\section{Professional organisations}

(a) Professional associations

BVPäd, BDVT, dvct

ADS

(b) Providers' associations

DVV, DEAE, KEB, Wuppertal Circle

ZLUS, U3A, DOIO, ZiSS

(c) Academic associations

DGfE, DGWF

l

Professionalisation organisations

Universities

Universities

ACE providers

ACS, ACE providers

Finally, from the perspective of professionalism, we can discuss the extent to which these organisations (Table 1) most typically represent an orientation towards professional, state-regulatory and market-oriented models (Freidson, 2001). In Germany, the professionalisation surge of the 1970s was strongly influenced by a state-controlled professionalisation model. The BVPäd continues this tradition and combines it with the hope for strong autonomous self-control within the profession. At the same time, a successful hybridisation of professional self-organisation with a strong market-oriented logic is emerging in both professional associations in the area of "training", where this is offered freely on a market, but its value is secured by community-based mutual recognition. The providers' associations link market with bureaucratic logics, as they sometimes play a dual role as providers and beneficiaries of professional development. In Slovenia, there is no organisation that typically represents or fits into one model; rather, hybrid forms can be observed. ACS can be placed in a triangle between profession, market, and bureaucracy, as it provides professional training programmes, research results and evaluations, offers programmes to both liberal and marketoriented AE providers, and is funded by the national government, EU projects, and market activities, whereas ADS and other providers' associations can best be 
placed between profession (they all offer professionally controlled training) and bureaucracy (state and EU project funding and regulation).

\section{Conclusion}

In this paper, we argue that the classical idea of a contradiction between organisations and professions has to be abandoned in favour of an analysis of the connections between organisational and professional practices. This led us to look at both professional and professionalisation organisations as relevant institutionalised contexts where the professionalisation of ACE is continuously negotiated. The results of our comparative analysis, which focused on the role organisations play in the professionalisation of AE in Germany and Slovenia, show that (1) providers' associations as professional organisations are the most numerous and important organisations in both countries, while in Germany a wider range of professional and scientific associations are active in the field; (2) universities in both countries are the most important professionalisation organisations; (3) in both countries, different courses for the continuing professional development of $\mathrm{AE}$ offered by public, private, and civil society providers are available, whereas in Slovenia, a system for continuing professional development managed by the national institute (ACS) is in place as well; (4) in both countries, hybridisations between professionalism, the market, and bureaucracy exist: whereas hybridisations between the professional and market logic tend to dominate in Germany, professional and state control come closer together in Slovenia; (5) the main differences between the two countries arise from the state-society contexts, because preserving the traditional regional and institutional diversity in Germany is achieved at the price of a unified occupational profile, which is actively safeguarded by the state, and a more common concept of professionalisation than the one we find in Slovenia.

\section{References}

ACS. (2015). Professional training of adult educators at the Slovenian Institute for Adult education. Ljubljana: ACS.

ACS. (2020). Andragoško spopolnjevanje. Retrieved from https://izobrazevanje.acs.si/programoteka_as/index.php?nid=5000\&id=453

ADS. (2020). O društvu. Retrieved from https://www.andragosko-drustvo.si/o-drustvu/

Andersson, P., Köpsén, S., Larson, A., \& Milana, M. (2013). Qualification paths of adult educators in Sweden and Denmark. Studies in Continuing Education, 35(1), $102-118$. 
BAMF. (2019). Das Bundesamt in Zablen 2018. Nürnberg: Bundesamt für Migration und Flüchtlinge.

BMAS, \& BMBF. (2019). Wissen teilen. Zukunft gestalten. Zusammen wachsen: Nationale Weiterbildungsstrategie [Strategiepapier]. Retrieved from https://www.bmas.de/ SharedDocs/Downloads/DE/Thema-Aus-Weiterbildung/strategiepapier-nationale-weiterbildungsstrategie.pdf

Breitschwerdt, L., Lechner, R., \& Egetenmeyer, R. (2019). The "new professionalism" in adult and continuing education - a multi-level perspective. Adult Education and Development, 86, 88-95.

Council of the European Union. (2011). Council resolution on a renewed European agenda for adult learning. OJ No. C 372/1, 20/12/2011. Brussels: Official Journal of the European Union.

Desjardins, R. (2017). Political economy of adult learning systems: Comparative study of strategies, policies and constraints. London: Bloomsbury Academic.

DGFE. (2006). Kerncurriculum für konsekutive Bachelor/Master-Studiengänge im Hauptfach Erziehungswissenschaft mit der Studienrichtung Erwachsenenbildung/Weiterbildung. Retrieved from https://www.dgfe.de/fileadmin/OrdnerRedakteure/Stellungnahmen/2006_KCE_EB-WB_konsekutiv.pdf

DIE. (2017). Leitbild. Bonn: Deutsches Institut für Erwachsenenbildung.

DOIO. (2020). Društvo DOIO. Retrieved from http://drustvo-doio.splet.arnes.si/

DiMaggio, P. J., \& Powell, W. W. (1983). The iron cage revisited: Institutional isomorphism and collective rationality in organizational fields. American Sociological Review, 48(2), 147-160. https://doi.org/10.2307/2095101

DVV International. (2013). Curriculum GlobalE. Bonn: DVV International and DIE.

Egetenmeyer, R., Breitschwerdt, L., \& Lechner, R. (2019). From "traditional professions" to "new professionalism": A multi-level perspective for analysing professionalisation in adult and continuing education. Journal of Adult and Continuing Education, 25(1), 7-24. https://doi.org/10.1177/1477971418814009

Eurydice. (2020). National Education Systems. Retrieved from https://eacea.ec.europa. eu/national-policies/eurydice/national-description_en

Field, J. (2019). Adult education centenaries: Lifewide and worldwide. International Journal of Lifelong Education, 38(5), 485-487.

FilozofSKA FAKULTETA. (2021a). O oddelku za pedagogiko in andragogiko. Retrieved from https://pedagogika-andragogika.ff.uni-lj.si/en/node/1993

Filozofska fakulteta. (2021b). Pedagogy. Retrieved from http://www.ff.um.si/oddelki/ pedagogika/studijski-programi.dot?language_id=1

Filozofska fakulteta. (2021c). Programi za izpopolnjevanje. Retrieved from https:// www.ff.uni-lj.si/izobrazevanja/center-za-pedagosko-izobrazevanje/programi-zaizpopolnjevanje

Freidson, E. (2001). Professionalism: The third logic. Cambridge: Polity Press.

Gieseke, W. (2008). Zwischen Verberuflichung und Professionalität: 50 Jahre Support für die Profession Erwachsenenbildung. In E. Nuissl (Ed.), 50 Jahre für die Erwachsenenbildung (pp. 45-62). Bielefeld: W. Bertelsmann. 
Goode, W. J. (1957). Community within a community: The professions. American Sociological Review, 22(2), 194-200.

Greenwood, R., Suddaby, R., \& Hinings, C. R. (2002). Theorizing change: The role of professional associations in the transformation of institutionalized fields. Academy of Management Journal, 45(1), 58-80. https://doi.org/10.5465/3069285

Grotlüschen, A., \& Haberzeth, E. (2018). Weiterbildungsrecht. In R. Tippelt \& A. von Hippel (Eds.), Handbuch Erwachsenenbildung/Weiterbildung (pp. 543-563). Wiesbaden: Springer VS.

Grotlüschen, A., Stammer, C., \& Sork, T. J. (2020). People who teach regularly: What do we know from PIAAC about their professionalization? Journal of Adult and Continuing Education, 26(1), 125-148.

Grunert, C., Ludwig, K., Radhoff, M., \& Ruberg, C. (2016). Studiengänge und Standorte. In H. C. Koller, H. Faulstich-Wieland, H. Weishaupt, \& I. Züchner (Eds.), Datenreport Erziehungswissenschaft 2016 (pp. 19-69). Opladen, Berlin, Toronto: Barbara Budrich.

Jarvis, P., \& Chadwick, A. (1991). Training adult educators in Western Europe. London: Routledge.

Jütte, W., Nicoll, K., \& Salling Olesen, H. (2011). Editorial: Professionalisation the struggle within. European Journal for Research on the Education and Learning of Adults, 2(1), 7-20.

Kurtz, T. (2002). Berufssoziologie. Bielefeld: Transcript.

Marshall, T. H. (1939). The recent history of professionalism in relation to social structure and social policy. The Canadian Journal of Economics and Political Science, 5(3), 325-340.

Martin, A., \& Langemeyer, I. (2013). Demografie, sozioökonomischer Status und Stand der Professionalisierung - das Personal in der Weiterbildung im Vergleich. In DIE (Ed.), Trends der Weiterbildung. DIE-Trendanalyse 2014 (pp. 43-67). Bielefeld: W. Bertelsmann.

Martin, A., Lencer, S., Schrader, J., Koscheck, S., Ohly, H., Dobischat, R., ... Rosendahl, A. (2016). Das Personal in der Weiterbildung: Arbeits- und Beschäftigungsbedingungen, Qualifikationen, Einstellungen zu Arbeit und Beruf. Bielefeld: W. Bertelsmann.

Mermolja, E., Benko, A., Grželu, A., \& Ličen, N. (Eds.). (2019). Soustvarjamo družbo znanja: Zbornik ob 60-letnici Zveze ljudskih univerz Slovenije. Ljubljana: Zveza ljudskih univerz Slovenije.

Merriam, S. B., \& Brockett, R. G. (2007). The profession and practice of adult education: An introduction. San Francisco: John Wiley \& Sons.

Mieg, H. (2016). Profession: Begriff, Merkmale, gesellschaftliche Bedeutung. In M. Dick, W. Marotzki, \& H. Mieg (Eds.), Handbuch Professionsentwicklung (p. 638). Bad Heilbrunn / Obb.: Klinkhardt.

Mikulec, B. (2019). Competences of adult education professionals in the European and Slovene context. Journal of Adult and Continuing Education, 25(1), 25-44. 
Mikulec, B., \& Jelenc Krašovec, S. (2016). Marketising Slovene adult education policies and practices using mechanisms of the Europeanisation of education. European Journal for Research on the Education and Learning of Adults, 7(2), 151-170.

Ministrstvo Za šOlSTVO IN ŠPORT. (2011). Bela knjiga v vzgoji in izobraževanju v Republiki Sloveniji. Ljubljana: Ministrstvo za šolstvo in šport.

Mintzberg, H. (1989). The structuring of organizations. In D. Asch \& C. Bowman (Eds.), Readings in Strategic Management (pp. 322-352). https://doi. org/10.1007/978-1-349-20317-8_23

Mohorčič Špolar, V. A. (2011). Učitelji v izobraževanju odraslih. In T. Čelebič, O. Drofenik, A. Ivančič, S. Jelenc Krašovec, V. A. Mohorčič Špolar \& E. Zver (Eds.), Izobraževanje odraslih v Sloveniji: stanje in izzivi (pp. 165-187). Ljubljana: Pedagoški inštitut.

National Assembly. (2013). Resolucija o Nacionalnem programu izobraževanja odraslih v Republiki Sloveniji za obdobje 2013-2020 (ReNPIO). Retrieved from http://www. pisrs.si/Pis.web/npbDocPdf?idPredpisa=RESO97\&type=pdf

Nuissl, E., \& LATTKe, S. (Eds.). (2008). Qualifying adult learning professionals in Europe. Bielefeld: Bertelsmann.

Parsons, T. (1939). The professions and social structure. Social Forces, 17(4), 457-467.

Parsons, T. (1968). Professions. In D. L. Sills (Ed.), International Encyclopedia of Social Sciences (Vol. 12, pp. 536-547). Retrieved from https://www.encyclopedia.com/ social-sciences-and-law/economics-business-and-labor/businesses-and-occupations/professions

PedagošKa fakulteta. (2021). Study programmes. Retrieved from https://www.pef.upr. si/study_programmes/

Powell, W. W. (1990). Neither market nor hierarchy: Network forms of organisation. Research in Organizational Behavior, 12, 295-336.

RESEARCH VOOR BELEID. (2010). Key competencies for adult learning professionals, contribution to the development of a reference framework of key competences for adult learning professionals, final report. Zoetermeer: Research voor Beleid.

Schwarz, J. (2016). Umkämpfte Professionalität: Eine praxistheoretische Analyse zur Institutionalisierung pädagogischer Praxisformen im Feld der Gründungsberatung (Dissertation, Philipps-Universität). Retrieved from http://dx.doi.org/10.17192/ z2016.0940

Seitter, W. (2007). Geschichte der Erwachsenenbildung. Eine Einführung. Bielefeld: W.Bertelsmann.

Stichweh, R. (2006). Professionen in einer funktional differenzierten Gesellschaft. Retrieved from https://www.fiw.uni-bonn.de/demokratieforschung/personen/stichweh/pdfs/53_stw-prof.fd.pdf

U3A. (2020). Slovensko univerzo za tretje življenjsko obdobje. Retrieved from http://www. utzo.si/

Williamson, O. E. (1973). Markets and hierarchies: Some elementary considerations. The American Economic Review, 63(2), 316-325. 
ZaKon o IZOBRaŽEVANJu odRaslih [ZIO]. (2018). Retrieved from http://www.pisrs.si/ Pis.web/pregledPredpisa?id=ZAKO7641

ZISS. (2019). ZiSS Slovenije. Retrieved from https://www.ziss.si/home/

ZLUS. (2020). Izobraževanja. Retrieved from https://www.zlus.si/projekti-zlus/izobrazevanjal

Jörg Schwarz ${ }^{4}$

Univerzitet Helmut Šmit, Nemačka

Borut Mikulec ${ }^{5}$

Univerzitet u Ljubljani, Slovenija

\section{Uloga organizacija u profesionalizaciji nastavnika u obrazovanju odraslih u Nemačkoj i Sloveniji}

Apstrakt: U ovom radu analiziraćemo ulogu koju organizacije za obrazovanje odraslih i kontinuirano obrazovanje igraju u profesionalizaciji nastavnika za odrasle time što pružaju i definišu mogućnosti za osnovno profesionalno obrazovanje i kontinuirani profesionalni razvoj u dve države Centralne Evrope - Nemačkoj i Sloveniji. U teorijskom smislu, naša diskusija proizilazi od klasične teorije profesije, teorije organizacije i diskursa „novog profesionalizma“, dok u empirijskom pogledu sprovodimo uporednu analizu između dve zemlje, i ujedno diskutujemo o sličnostima i razlikama u kontekstu države i društva, o profesionalnim organizacijama i organizacijama za profesionalizaciju. Prema našim saznanjima, profesionalne organizacije i organizacije za profesionalizaciju predstavljaju glavni institucionalizovani kontekst u kojem se pregovara o profesionalizaciji obrazovanja odraslih i kontinuiranog obrazovanja, dok to podržava snažni kontekst države i društva u Sloveniji, za razliku od Nemačke, gde se tradicionalna regionalna i institucionalna raznolikost ostvaruju po cenu objedinjenog profila zanimanja.

Ključne reči: Nemačka, organizacije, profesionalizacija nastavnika za odrasle, Slovenija.

\footnotetext{
${ }^{4}$ Dr Jörg Schwarz je istraživač postdoktorand na Univerzitetu Helmut Šmit, Nemačka (joerg.schwarz@hsu-hh.de).

${ }^{5}$ Dr Borut Mikulec je docent na Univerzitetu u Ljubljani, Slovenija (borut.mikulec@ff.uni-lj.si).
} 